Eurostudia

\title{
Introduction: Resistance and Collaboration from Today's Observation Post
}

\section{Barbara Thériault et Lucian Turcescu}

Volume 10, numéro 1, 2015

From Today's Observation Post: Collaboration and Resistance under Communism

Vues du poste d'observation du présent : collaboration et résistance sous le communisme

Kollaboration und Widerstand im Kommunismus - Betrachtungen aus heutiger Sicht

URI : https://id.erudit.org/iderudit/1033880ar

DOI : https://doi.org/10.7202/1033880ar

Aller au sommaire du numéro

Éditeur(s)

Le Centre canadien d'études allemandes et européennes

ISSN

1718-8946 (numérique)

Découvrir la revue

Citer ce document

Thériault, B. \& Turcescu, L. (2015). Introduction: Resistance and Collaboration from Today's Observation Post. Eurostudia, 10(1), v-x.

https://doi.org/10.7202/1033880ar

Tous droits réservés $@$ Le Centre canadien d'études allemandes et européennes, 2015
Ce document est protégé par la loi sur le droit d'auteur. L'utilisation des services d’Érudit (y compris la reproduction) est assujettie à sa politique d'utilisation que vous pouvez consulter en ligne.

https://apropos.erudit.org/fr/usagers/politique-dutilisation/ 
Barbara Thériault (Université de Montréal)

Lucian Turcescu (Concordia University)

When we started thinking about the present issue of Eurostudia we had a theme in mind, resistance and collaboration in Romania and in a select number of countries located in Central and Eastern Europe and the former Soviet Union (the former Czechoslovakia, German Democratic Republic and Republic of Tajikistan) after World War II. At the center of our attention were the collaboration and resistance of religious groups' members and leaders with political authorities such as Communist Party structures, but also the police and secret police forces. From a project proposal, to a workshop held at the Université de Montréal on 27 February 2015, to numerous face-to-face and epistolary exchanges until the publication of this special issue, we realized the importance of the present in understanding the past or how resistance and collaboration have been interwoven into the politics of memory of actors and observers who study them. Of course, changes of regimes twisted roles and moral positions and, in turn, the way we think and write about changes and people's involvement in them. Acknowledging our discussions and the articles present in this issue, we titled it "From Today's Observation Post: Collaboration and Resistance under Communism."

Exploring the "present of things past" required placing oneself outside of the current public debates in order to comprehend better how they influence the understanding of things past. It also raises conceptual and methodological issues, as well as moral dilemmas. In working together, the participants in the workshop-political scientists, sociologists, anthropologists, historians, and religious scholars-made the initial object turn so as to exhibit its many facets. On 
the conceptual level, they address the following questions: How is one to assess resistance and collaboration? Should we take the motives underlying action or the consequence of actions as starting points? Are resistance and collaboration, concepts embedded in political debates, still appropriate concepts to grasp what is at play? Should we talk, as Hélène Thibault suggests, of "accommodation" instead of resistance or resignation? The authors tackle empirical questions too: What is the role of anti-communist armed resistance in the politics of memory (Monica Ciobanu)? How do politically uninvolved actors such as pilgrims unwittingly play a role in Romania's new ideological landscape (Monica Grigore)? On the methodological level, the authors ask: How do we aptly deal with the sensitive material stored by repressive political police forces? How much credit should we give to secret information that cannot be corroborated from other sources? How to read the Securitate files, especially when they deal with a past that strikes close to home (Cristina Plamadeala)? How does what we do with our informants as sociologists relates with the work of secret agents (Barbara Thériault)? As it turns out, the methodological questions often turn into moral dilemmas.

Having arrived at the publication stage, the two editors sit down to reflect on the texts presented here and to discuss aspects pertaining to the issue as a whole. And before sending the texts to the publisher, they want to take the opportunity to thank all the participants in the workshop for their contributions, although not all of them were able to submit their contributions to Eurostudia. A special thank-you should go to Monica Grigore, for commenting on all the articles, besides the other reviewers.

\section{Somewhere in Montréal, September 2015:}

BT: Lucian, do you think that time, more than 25 years after regime changes, and physical distance, researching and thinking about Europe in Montreal, makes it easier to distance ourselves from the powerful narratives about the communist era in the light of the 1989 events. In 1990s, it was difficult to grasp the ongoing social and political transformations; we were often emotionally involved. Does 
the distance allow us as researchers to see things we might not have fully seen before?

I now realize that, while examining controversies within East German churches in the 1990s, I had not seriously challenged the East German churches' discourse. Specifically, I had not challenged what was perceived as "facts." In his article Miroslav Tížik makes a similar argument about the dissident church in Czechoslovakia.

What about the image of the collaborating church in Romania? Don't you think it is fair to say that it is now, more so than in the 1990s, time for post-communist or transformation studies?

LT: As a historian of religion, I cannot agree more, Barbara, that hindsight, newly opened archives, new revelations about the past, new historical interpretations, and even physical distance all help us to understand the past differently than, say, 25 years ago. At this time of European Union integration, many have argued that post-communist perspectives are no longer appropriate. I somewhat agree with that, but obviously in the area of resistance and collaboration, one cannot so easily bracket the post-communist debates that need to be had, since they involve the communist past.

BT: Could you come back to the image of the collaborating church in Romania? How did your take on it evolve? I ask you because I see a shift between your book Religion and Politics in Post-communist Romania and the article you and Lavinia publish in our issue. ${ }^{1}$

LT: Over the past decade, our understanding has evolved due to access to new archival materials and court cases, which were not available at the time when we wrote that book in 2005-2006. We now have a more nuanced understanding of the figure of Patriarch Justinian Marina, as both collaborator with the communists and defender of his church. His actions were accommodationist after

\footnotetext{
${ }^{1}$ Stan, L. and L. Turcescu (2007). Religion and Politics in Post-Communist Romania. Oxford University Press.
} 
all, to use Thibault's word. We also have a better grasp of why a post-communist church leader such as Teoctist tried to use the figure of Marina to change the perception about his own attitude toward the communists.

BT: I could not help but notice that several articles deal with individuals or in depth's individual cases: Cristina Plamadeala's, yours and Lavinia Stan's, mine. Miroslav Tížik's also sees a way to get out of dominant narratives at the end of his paper by hinting at what he calls it a "history from below." Do you see a connection to our theme? Does it represent a privileged way to deal with resistance and collaboration, or accommodation? And do you think some colleagues would shy away from such approaches in their attempts to map out patterns?

LT: As I pointed out, we have now access to more material, it is now possible to put forth such an approach. Yet, I don't want to give up delineating patterns and still hold on to concepts such as resistance and collaboration. What is your take on that?

BT: Resistance and collaboration are largely political concepts. I understand that they engage different circles of people in a debate. I think we have to acknowledge this. For my part, however, I'd like to encourage new ways to work with the material available to us. I see an important avenue in the daily lifeaway from dominant narratives. "Working from below" does not mean renouncing patterns or historical ideas, as Monica Grigore's piece shows in her recent ethnography of pilgrims. Starting from below, she helps us understanding today's Romania and the promotion of a particular reading of the past. Next to methodological approaches I think we need to explore new writing formats. This is why I'm glad we could work with Eurostudia. The journal is open to different formats, and the authors of the present issue certainly took up that challenge. Some of the problems we encountered while researching could be approached in an original manner and offered a solution because we had the freedom to play with various formats: country reports, a book review, a historian's journey into her family's past, articles of different lengths.

LT: Absolutely, I agree with you that the journal allowed us to explore with new formats (including open access, which I experience for the first time), writing 
styles, and thus further contribute to our respective fields of expertise in different ways.

BT: Working predominantly on Romania in the frame of this particular issue, but with people specialized in other national contexts made me see aspects which are not directly dealt with in the issue: How, for instance, anti-communism is largely absent on the territory of the former German Democratic Republic or how stable the situation has been there in the last 25 years in comparison to Romania. What did the issue make you see you might not have realized before?

LT: I am always happy to learn from colleagues who specialize in other Eastern and Central European countries. Their perspectives are enriching for me. I learned, for example, that in a country like the former Czechoslovakia, there was disagreement inside the church hierarchy itself about whether or not to support the communist regime-something which, as you pointed out to me, was also the case in the former German Democratic Republic. If this type of debate existed in the Romanian Orthodox Church, we certainly did not know about it. This tells us about the character of the church, in the sense of divergent opinions being tolerated, or about the level of control the communists imposed by allowing or eliminating divergent opinions.

BT: And about discussions about collaboration?

LT: Indeed. Also, I was surprised to discover how much more debate about resistance and collaboration under the Nazi occupation existed even under communism in Czechoslovakia than in Romania.

LT: Barbara, I would like to learn your answer to the same question. You are a sociologist who has worked on East Germany. Please tell us how this issue of Eurostudia has helped you in your research.

BT: I've already mentioned the absence of anti-communism on the territory of the former German Democratic Republic. In my piece, I stress the importance of the Securitate in working with existing networks-I call these networks "bourgeois." Comparing Romania with (fascist and then communist) Germany, I suggest that the study of these existing networks and the gossips that pertain to them helps us 
to grasp and explain why a high number of Romanians collaborated with the secret services; there was something banal, about collaboration. I realize, that this might be a bit shocking - as the participants at the workshop did not fail to point it out to me. Of course, I don't mean that all collaboration was banal.

LT: Well, let's hope that the present issue will also help scholars of postcommunism and kick off a larger discussion on new avenues for research. 